\title{
Synthesis
}

\section{Science for Place-based Socioecological Management: Lessons from the Maya Forest (Chiapas and Petén)}

\author{
$\underline{\text { David Manuel-Navarrete }}^{1}$ Scott Slocombe $^{2}$, and $\underline{\text { Bruce Mitchell }}^{3}$
}

\begin{abstract}
The role humans should play in conservation is a pervasive issue of debate in environmental thinking. Two long-established poles of this debate can be identified on a preservation-sustainable use continuum. At one extreme are use bans and natural science-based, top-down management for preservation. At the other extreme is community-based, multidisciplinary management for sustainable resource use and livelihoods. In this paper, we discuss and illustrate how these two strategies have competed and conflicted in conservation initiatives in the Maya forest (MF) of the Middle Usumacinta River watershed (Guatemala and Mexico). We further argue that both extremes have produced unconvincing results in terms of the region's sustainability. An alternative consists of sustainability initiatives based on place-based and integrated-knowledge approaches. These approaches imply a flexible combination of disciplines and types of knowledge in the context of nature-human interactions occurring in a place. They can be operationalized within the framework of sustainability science in three steps: 1) characterize the contextual circumstances that are most relevant for sustainability in a place; 2) identify the disciplines and knowledge(s) that need to be combined to appropriately address these contextual circumstances; and 3) decide how these disciplines and knowledge can be effectively combined and integrated. Epistemological flexibility in the design of analytic and implementation frameworks is key. Place-based and integrative-knowledge approaches strive to deal with local context and complexity, including that of human individuals and cultures. The success of any sustainability initiative will ultimately depend on its structural coupling with the context in which it is applied.
\end{abstract}

Key Words: contextualization; integrated conservation; Mayaforest; place-based; sustainability initiatives

\section{INTRODUCTION}

The role humans should play in conservation is a pervasive issue of debate in environmental thinking. Two long-established poles of this debate can be identified using a preservation-sustainable use continuum. At one end, banning of use is advocated as the main strategy for conservation, and biological science is considered to be the main source of knowledge for conservation policy and design. At the other end, the use of the resource is regarded as a necessary, although insufficient, condition for conservation, and both biological and socioeconomic insights are needed for policy making.

Concerns about the pertinence and effectiveness of efforts deployed for reversing the negative transformations of tropical ecosystems have recently come to the forefront of this general debate. Initially, these efforts were mostly based on an exclusionary, command-and-control, governmentdriven conservation strategy implemented through the establishment of natural reserves. The proponents of this strategy used to invoke disciplinary (often biological and ecological) science as the only guiding principle for effective conservation. However, during the 1990s, international donors and others began to promote a more inclusive, community-based strategy for conservation. This new strategy brought economic and political sciences to the forefront of conservation efforts.

In this paper, we discuss and illustrate how the two aforementioned strategies have guided governmental conservation initiatives in the Maya forest (MF) of

\footnotetext{
${ }^{1}$ United Nations Economic Comission for Latin America and the Caribbean, ${ }^{2}$ Geography and Environmental Studies, Wilfrid Laurier University,

${ }^{3}$ Department of Geography, University of Waterloo.
} 
the Middle Usumacinta River watershed (Guatemala and Mexico) during the last three decades. We further argue that these strategies have yielded unconvincing results in terms of the region's sustainability. We suggest that initiatives based on place-based and integrated-knowledge approaches would enhance the effectiveness of strategies for the sustainability of the MF socioecological system. These approaches are consistent with the objectives of the new field of sustainability science, which has been defined as seeking "to understand the fundamental character of interactions between nature and society and to encourage those interactions along more sustainable trajectories" (Kates et al. 2001:641). It can also contribute to the notion of interdisciplinary conservation science characterized by "a more sophisticated understanding of social-ecological interactions" (Berkes 2004:621).

\section{ANALYTICAL APPROACH}

Place-based and integrated-knowledge approaches imply a flexible combination of as many disciplines (and, eventually, knowledge types) as judged appropriate in the light of contextual circumstances (i.e., nature-human interactions occurring in a place). We propose that this approach can be operationalized within the framework of sustainability science through three steps. First, to characterize those contextual circumstances that are most relevant for sustainability in a place. Second, to identify the disciplines and knowledge(s) that need to be combined for appropriately addressing these relevant contextual circumstances. A third step, not carried out in this paper, is to decide how these disciplines and knowledge are to be effectively combined and integrated. In this framework, it is assumed that one of the causes that explains the ineffectiveness of sustainability initiatives to appropriately address contextual circumstances is the lack of epistemological flexibility in their design. Sustainability initiatives are often designed according to predetermined and rigid epistemological frameworks (i.e., frameworks determining which knowledge is relevant). Furthermore, these frameworks are often formulated within academic settings more connected with academic discourses than with the realities of particular places (ManuelNavarrete et al. 2004). Here, we aim to make an argument for ex-post epistemological decision making that takes into consideration an ample array of knowledges in the light of their usefulness for addressing contextual circumstances.
The characterization of relevant contextual circumstances for addressing a complex socioecological systems' sustainability is a daunting task. Ideally, this characterization should be undertaken through interdisciplinary teamwork (i.e., promoting explicit discussions across disciplinary borders). Moreover, it should always be understood as an exercise involving, unavoidably, a certain degree of subjectivity, and resulting in provisional and everimprovable outcomes. However, we believe at least that individual researchers with interdisciplinary backgrounds can perform initial estimations that may be useful as inputs for subsequent teamwork discussion, and interdisciplinary teamwork may not always be feasible. In any case, we advocate modes of inquiry based on promoting as much as possible the researcher's exposure to and experiencing of the complex socioecological realities and meanings of the place under study, including biophysical, socioeconomic, and cultural aspects.

In the case of the MF, 5 months of fieldwork based on an ethnographic approach were conducted in the area during 2001 and 2002 (Manuel-Navarrete 2005). The core of this approach consisted of firsthand participation in some initially unfamiliar social worlds related to the conservation of the MF, and the production of written accounts of those worlds by drawing upon such experience (Emerson et al. 1995). A broad range of people knowledgeable about and interested in the MF's sustainability was contacted, and ten rural communities in the area were visited. A great diversity of information, data, experiences, emotions, and perspectives was collected through (1) analysis of secondary data, (2) conversations with professionals working in the area, (3) dialogues with people inhabiting the MF, (4) participant observation in several local communities, and (5) attendance at workshops and organizational meetings.

The outcome of this close examination of the MF nature-human interactions is a story of how these interactions, and other contextual elements, were considered, or not, by the implemented conservation and sustainability initiatives. This story is summarized in the following section. Scientific knowledge, the analysis of conflicts, and local peoples' meanings and perceptions of their own interactions with government policies provide good insights for characterizing biophysically, socioeconomically, and culturally relevant contextual circumstances. In the discussion section, available evidence regarding the effectiveness of these 
conservation initiatives is reviewed and assessed. The next step, the identification of knowledges and disciplines to be integrated for the design of more effective place-based sustainability initiatives in the $\mathrm{MF}$, is carried out as a preliminary, thoughtprovoking illustration. Finally, some methodological conclusions and recommendations are drawn.

\section{EXAMINING CONSERVATION INITIATIVES IN THE MAYA FOREST}

The MF of the Usumacinta watershed is shared by the Mexican State of Chiapas and the Guatemalan Department of Petén. About $50 \%$ of its nearly 1000 000 inhabitants (in 2000) belong to one of the more than 20 ethnic groups of Mayan origin. The economy of the region is based on primary activities. The main agrarian activity of the peasant communities is the harvesting of corn for their own consumption. However, cattle ranching occupies a significant part of the territory. Forestry, the extraction of forest products, and oil extraction are also important. The degradation of natural resources caused by these economic activities is raising important concerns about the sustainability of the region. During the last three decades, national governments and international NGOs have reacted to these concerns by implementing conservation initiatives that largely consist of biosphere reserves, national parks, and other protected areas. The most important in terms of spatial extent and allocation of resources are the Montes Azules Biosphere Reserve (MABR) established in Chiapas, Mexico, and the Maya Biosphere Reserve (MBR) established in Petén, Guatemala. We argue that these initiatives were founded on the preservation of the biophysical integrity of forest ecosystems, whereas socioeconomic and cultural contextual circumstances were poorly considered in both design and implementation.

Local resistance and alternative sustainability strategies, in tune with socioeconomic and cultural contextual circumstances, emerged partly in response to the institutional designs implemented through the MABR and MBR. We analyze the "Zapatista" ecosocial movement in Chiapas, and the community forest concessions in Petén. Regarding Chiapas, the relationships between the promoters of the MABR (e.g., the Mexican government and some NGOs) and the Zapatista are marked by strong confrontation. In Petén, a self-organizing community forest association, ACOFOP, has greatly contributed to sustainability, even if the promoters of the MBR did not intend its emergence.

A main point of this paper is that governmental initiatives in the MF would have been more effective in promoting sustainability if their design and implementation had considered a broader spectrum of contextual circumstances. For example, taking into consideration the local meanings assigned to a place. Confrontation with local communities could have been more efficiently managed and significant venues of collaboration with local people and local perspectives could have created sustainability synergies. We acknowledge that the decision to focus on some aspects of reality, and not others, when designing and implementing sustainability initiatives is often determined by historical and political considerations, as well as a society's power balances. However, we argue that it is also influenced by epistemological options and power issues, acting within the interface between knowledge and power, which tend to privilege particular explanations, narratives, and discourses. The critical examination of how knowledge is articulated and used, and the proposal of epistemologically flexible approaches such as the one presented here are fundamental for enhancing sustainability initiatives.

\section{The Montes Azules Biosphere Reserve, Mexico}

In 1978, the government of Mexico established the $3312-\mathrm{km}^{2}$ MABR. The reserve was designed following a blueprint prepared by several biological and ecological research institutions. Most of the reserve was designated either as "core zone" (77\%), or "buffer zone" $(21 \%)$ (leaving less than $2 \%$ of the reserve for "traditional use"). This zoning strategy is consistent with the notion that ecological integrity requires restricting certain natural areas to exclusively non-consumptive uses, such as tourism and scientific research. Eighty-five percent of the MABR fell within communal lands owned by the Lacandon ethnic group, but also shared with immigrants of other Mayan ethnic groups who had "invaded" the Lacandon communal lands. The other $15 \%$ of the reserve covered lands owned by Tzeltal and Chol communities (De Vos 2002).

The implementation of the MABR was slow and it remained a "paper park" (i.e., a park in name only) until the late 1980s (Vásquez-Sánchez et al. 1992). The first document related to the implementation of 
management actions for the MABR was published in 1990, but it was not until 1994 that the first operational office was established for the reserve. In 1990, several Mexican institutions and the U.S.based NGO Conservation International (CI) prepared a management plan (Carabias-Lillo et al. 2000). During the 1990s, stronger government, academic, and international support and involvement permitted more substantial advancement in conservation programs, research, infrastructure for protection, and monitoring activities. Many of these activities were oriented to preventing or removing "irregular settlements" (i.e., settlements with no legal ownership of the land on which people live and work).

The ethical legitimacy of the strategies based on the relocation of communities has been strongly questioned in numerous social and academic sectors, both within Mexico and abroad. Some influential Mexican academics have also critiqued this policy. For instance, Arturo Gómez-Pompa and Andrea Kaus (1999: 5983) commented that:

A system of protected areas represented perhaps a visionary model for the country, but the government has treated these sites as if they exist in a vacuum, unperturbed by human intervention or ecological change. It presumed the absence of humans before the establishment of the parks.

Other critics are more radical, and argue for transferring power and legitimacy to local communities for decisions about the state of the forest (e.g., Leyva-Solano and Ascencio-Franco 1996, Hernández-Gómez et al. 2003).

The major opposition to the MABR came from local communities, and has materialized in the active resistance through the Zapatista Army for National Liberation (EZLN; from the Spanish "Ejérito Zapatista de Liberación Nacional"). This local resistance started in the 1970s with the first threats of relocation of the immigrants who, fleeing from centuries of oppression, arrived in the forest beginning in the 1930s, and was manifested abruptly in 1994 with the temporary armed occupation of several towns and the invasion of 65000 ha of private lands (Bobrow-Strain 2004). Within the Lacandon forest inhabitants, divisions exist regarding the support for the EZLN. In general, the Chol ethnic group is considered to be more sympathetic to the Zapatistas than the Lacandons and Tzeltal. However, each family or individual has a different position. For instance, a Lacandon interprets the demands of the EZLN as follows:

I am going to explain it to you... The problem is that the government only wants its own benefit. There is a lot of money, but everything is kept by the political [Lacandon use the term "political" for everything that is related with power and money outside the community]. The problem is the political, because before the elections, everybody promises that they are going to build schools, hospitals, roads, and they say they are going to help with everything, but after the elections they only think about themselves, about their families, and they do not do anything for others. What the Zapatista say is that we have had enough of this.

The EZLN represents, for some, an alternative to modernity embedding a reformulation, from the South, of the dominant perspective on sustainable development originating in the North (Toledo 2000). In our interpretation, the Zapatista concept of sustainability is based on an international ethics of hope and collaboration that embraces the diversity of people's perspectives, experiences, and environments. In formal terms, it combines elements of the MF biophysical realities, Mayan culture and spirituality, and the Mexican Revolution (e.g., Subcomandante Marcos 2004). The Zapatista discourse assumes that the main ethical challenge of humanity is "to build a world in which there is room for all the worlds." They oppose neoliberalism because biophysical realities indicate, in their view, that this system can only bring wellbeing for some, at the cost of the discomfort for many. As summarized by Michel (2001: 197):

[T]he Zapatistas are not inviting us to take power, but to fill ourselves with a tenderfury to realize a revolt of love, a moral revolution against the structural violence, against oppression, and against any kind of tyranny exercised, autocratically, by those who, through obedience, refuse to be in command. In other words, they invite us to constitute the International of Hope (in reference to a world movement against inequity) and to globalize the solidarity 
with all the excluded who have poverty as their present and dignity as their future. In synthesis, they invite us to create the possible Utopia. [The expressions in boldface are mottos commonly used by the Zapatistas.]

Many Mayan and non-Mayan people subscribe to the Zapatista strategy. On 1 January 2003, about 20 000 Zapatistas marched in San Cristóbal de las Casas wearing masks. Most were indigenous people from rural communities, but the Zapatista movement and discourse includes people from diverse countries and occupations. In February 2003, the "II Encounter Against Neoliberalism" was held in a rural community of the Lacandon forest. This meeting attracted 700 people from more than 100 organizations and nine countries. In our view, the final declaration from this event shows the cultural context in which the MABR was implemented. We reproduce here the first five points of the final declaration:

We, indigenous and non-indigenous, women and men who emerged from the corn, who still practice that which our grandmothers and grandfathers taught us since we were children, that is, to work, to respect Mother Earth, to learn that we depend on her and from her we live, to learn to sustain ourselves, to not expect that someone else will teach us how to live, (...) This is our word: (1) We call everybody without distinctions of party, religion, sex, or color to walk together, holding our hands to live in peace with dignity and justice, and to live without the Puebla-Panama Plan, (2) in order to defend our seeds and our identity, the collective work is a real alternative for our people. Live it! (3) in respect with nature, we say no to pesticides and produce healthy foods without chemical poisons, (4) we respect life and say no to dams, (5) we weave ideas from what is common, being enriched with the differences for building unity and improving life in community.

The Mexican government responded to the EZLN with aggressive militarization of the area. The government and international environmental NGOs often interpret the peasants' demands relating to the forestlands as a threat to biodiversity and sustainability (Hernández-Gómez et al. 2003). The Zapatistas are not considered as a relevant element for sustainability, except as a menace to be overcome. In 1995, the Mexican government initiated a negotiation process with the EZLN that produced the San Andrés agreements, in which the government committed to improving the representation, autonomy, and material opportunities of indigenous people, and to withdrawing the army from Chiapas. However, this commitment has not yet been translated into any changes in Mexican legislation or federal policies in the Lacandon region, including conservation policies. The reaction of the EZLN to the government's lack of compliance with the San Andrés agreements has been the creation of the socalled "good government assemblies" or "caracoles" (Spanish word for snails) as a form of selforganizing the pro-Zapatista communities, which are only accountable to the community's members. The "caracoles" represent a genuine attempt by some MF inhabitants to take control of their own development.

\section{The Emergence of the Biosphere Reserve Model in Petén, Guatemala}

On the Guatemalan side of the MF, the $21221-\mathrm{km}^{2}$ Maya Biosphere Reserve (MBR) was legally established in 1990. The reserve was supported by generous funds from the U.S. Agency for International Development (USAID), and several international NGOs through the Maya Biosphere Project. The operative role of USAID was limited to supervising each subprogram. Local and international NGOs competed for the funding without provision for any coordinating mechanism regarding their respective activities. The Guatemalan National Council for Protected Areas (CONAP; from the Spanish "Consejo Nacional de áreas Protegidas") could have had such a coordinating role. However, this institution, created in 1989, lacked experience, organizational culture, and enough resources to undertake effective coordination of these multiple efforts.

The design of the reserve followed a top-down technocratic approach. The zoning reflected biological and ecological criteria, chosen and applied by experts and bureaucrats with very limited field experience. As a result, several communities saw their land divided into different protection categories, and many peasants who were in the 
process of registering their land titles discovered that they now needed to negotiate their rights with CONAP (Milián et al. 2002). The Maya Biosphere Project included two subprograms: (1) Biosphere Administration and (2) Sustainable Resource Management for Income Generation. We argue that the latter considered a relatively broader set of contextual circumstances than the former.

The Biosphere Administration Subprogram was intended to enable the Guatemalan government "to enforce the legal protection of Biosphere resources before current widespread destructive practices cause further irreversible damage" (USAID 1990:8). The underlying narrative of this subprogram is that ecological integrity, defined as the full range of natural species and habitats in the region, is achieved through strict legal protection of "pristine" ecosystems. For this purpose, $7762 \mathrm{~km}^{2}$ were designated as a core zone in the MBR. However, enforcement of this strict protection faced multiple obstacles in Petén. Following the creation of the MBR, CONAP posted dozens of resource guards at various key places throughout the reserve. These posts eventually became a focus for local opposition to CONAP's conservation efforts (Ponciano 1998). At least four posts were burned between 1992 and 1993, and several guards were reported to have been threatened and beaten when they tried to control logging activities. CONAP officials were viewed as outsiders, whose only purpose was to restrict farmers' land use, thus reducing their already precarious quality of life (Clark 2000).

Confrontation may have had some positive effects in terms of enhancing the authority of the Conservation Agency in front of powerful illegal logging groups (consisting mainly of military and economic elites). A member of CONAP explains how he was enrolled in CONAP in 1990. He believes that, in those early times, the deployment of strict control was necessary in order to change a situation of anarchy in the exploitation of the forest resources:

CONAP, at the beginning, did not provide much information about its activities. The priority was to create obstacles to the unrestrained destruction of natural resources and to provide surveillance. I had just quit the army and was not afraid. There were others who had also been in the army. We were criticized for using force instead of promoting a social approach.
Nonetheless, CONAP's removal by force of the communities settled in the core areas is still vehemently resisted by the farmers, who do not have anywhere else to go. Using negotiation with the communities has produced some results, but these still are very limited (personal communication with CONAP personnel). For instance, Kline (2000) estimated that by 1999 more than 1800 people had been voluntarily relocated outside the core areas of the MBR. In 2003, CONAP signed an agreement for voluntary relocation with 13 communities (personal communication with CONAP personnel). However, this process is slow and costly (Chemonics International Inc. and IRG 2000). CONAP has used alternative strategies for relocation, such as the signing of goodwill agreements, and the realignment of some areas within the reserve as areas of special use, where some communities are allowed to stay, but only by following strict conditions dictated by CONAP.

The Sustainable Resource Management for Income Generation Subprogram of the MBR Project was implemented through the designation of $8484 \mathrm{~km}^{2}$ under the MBR's category of multiple-use zone. This designation was intended for the implementation of forest concessions and integrated conservationdevelopment projects. A forest concession involves public lands communally or privately managed for the sustainable use of forest products. Petén forest concessions are allocated for a period of 25 years, during which the concessionaires can commercialize the timber according to a General Management Plan approved by CONAP. Strict regulations and a process of timber certification are applied to the concessions of the MBR (Gretzinger 1998). The General Management Plan is just a minimal requirement for starting the co-management process. Once the concession starts operation, the annual operational plans are the tools for execution, control, and evaluation of the concessionaire activities by the state. The design and implementation of this subprogram was much more receptive to inputs from economics, natural resource management studies, and other social sciences. The basic strategy was to promote economic activities compatible with ecological integrity and the conservation of standing forests. The underlying narrative associated with this strategy is that the best way of securing ecological integrity is to create an economic stake in protecting the environment (i.e., demonstrating that the conservation of biological diversity is an economically rational choice) (Kremen et al. 2000). 
The procedure to obtain a concession is administratively complicated and plagued by technical requirements. However, the process took on a life of its own, and locals self-organized through the constitution of the Forestry Communities Association of Petén (ACOFOP; from the Spanish "Asociación de Comunidades Forestales de Petén"). The NGOs maintained their roles of providing technical support, but they focused on the commercialization of timber. The ACOFOP became a communitarian, relatively autonomous alternative, and acquired great political relevance in Petén. For instance, ACOFOP resisted the intent of controlling the forest concessions on the part of the industrial forestry interests of Guatemala. Although the process of forest concessions has been plagued by conflicts among communities, the state, forest industries, landowners, new immigrants, and NGOs, the model of community forest concessions is generally acknowledged in Petén as a good alternative for conserving the standing forest (this opinion was shared by all but one of the 25 professionals from government institutions and NGOs consulted about this issue during fieldwork). During fieldwork, we visited six of the 19 communities, and attended two of ACOFOP's general assemblies. People contacted in these communities, as well as the assistants to the general assembly, perceived that their local livelihoods had improved thanks to the income resulting from the sale of wood. In most cases, forest management was based on selective and rotating harvesting, with no silvicultural treatments except to promote natural regeneration. Harvesting was carried out following strict regulations to avoid any ecological impact resulting from logging activities. Community forest concessions benefit conservation in at least two ways. First, they are a clear incentive for local communities to preserve the forest as a source of income. Second, concessionaires defend the forest from new settlers. For instance, one of the community concessions legally established in the Sierra Lacandon National Park (in the core area of the MBR) frantically combatted the 1998 fires affecting their lands, and informed the authorities of the establishment of illegal settlement. In this community, the main threat to the forest they manage consists of clearing operations and incursions from immigrants settled in the Lacandon National Park.

Some scientists criticize forest concessions for their apparent lack of economic sustainability and their ecological impacts (e.g., Bowles et al. 1998, Rice et al. 2001). In Petén, it is argued by NGOs and also by the concessionaires that, without the financial and technical support of USAID and the accompanying NGOs, the communities would not be able to accomplish all the needed procedures. On the other hand, concessionaires claim that international consulting companies and the European and North American traders are the principal beneficiaries of the certification process (to initiate the certification process costs US\$10 000, whereas the annual assessment costs US\$1000).

Despite these controversies, concessionary communities have increased their incomes from the sale of timber. In 2002, the Biodiversity and Sustainable Forestry Indefinite Quantity Contract (BIOFOR-ICQ) estimated timber generated annual revenues of around US\$4 million for the 1700 concessionaires of the 12 organizations (representing 19 communities) that had completed the certification process. In addition, communitarian social organization has been enhanced, and some members have improved their financial and technical management skills. As expressed by a member of ACOFOP: "If we make a cost-benefit analysis of the process of forest certification, it would be clearly negative. However, there is a clear social benefit regarding organization and convincing people of the importance of conservation." More importantly, the forest concession has given legitimacy to the permanency of some villagers within the MBR. Now they are able to control a large amount of land, and are interested in keeping it free of invasion (Sundberg 1998).

\section{DISCUSSION}

Mexican and Guatemalan governments, supported by international funds and technical assistance, are implementing important conservation and sustainability initiatives in the MF. As we have shown, the design of these initiatives is quite narrow relative to the issues on which they focus and the people they include. First, they tend to view the complex reality of the MF only through the lenses of biology and ecology. Second, the issue of deforestation is defined only in biophysical terms. Third, social and human aspects are only considered as proximate causes of biophysical integrity loss. Fourth, conventional Western institutions and culture are taken as given. On one hand, these simplifications invariably result in important contextual circumstances 
being ignored. On the other hand, simplicity is often associated with efficiency, and policy-making effectiveness.

The assessment of the results of the MF biosphere reserves in terms of conservation and sustainability effectiveness is a highly complex task. Multiple factors affect, at different scales, the dynamics of deforestation and conservation. Available evidence shows mixed results. In the MABR, Mendoza and Dirzo (1999) observed that deforestation was 20 times greater outside the reserve than inside during 1974 and 1981, and six times greater for the period 1981-1991. Consequently, these authors suggest that: "It would appear that since its decree, in 1978, the reserve has played a significant role in diminishing the deforestation process in Lacandonia" (Mendoza and Dirzo 1999:1635). However, as the authors acknowledge, other factors such as geographic remoteness and the presence of roads could also explain this difference. Unfortunately, there are no published data for the period 19912005. Overall, the MABR could be judged as relatively effective in terms of conservation. However, sustainability assessments are much more controversial given the large social conflict that is ongoing in the region.

In Petén, Sader et al. (2000) estimated that average deforestation rates between 1990 and 1999 were higher in large parts of the core areas than in the multiple-use zone operated by forest concessions. In particular, the national parks Laguna del Tigre and Sierra Lacandon, which account for $62 \%$ of the MBR core area, experienced average annual deforestation rates of $0.28 \%$ and $0.92 \%$, respectively, peaking in the periods 1995-1997 and 1993-1995. Average annual deforestation rates in the multiple-use zone were $0.18 \%$, with a peak for the period 1993-1997. Furthermore, deforestation rates in these core areas were always higher after the creation of the reserve than the ones registered for the period 1986-1990. In contrast, deforestation rates in the multiple-use zone for the period 19971999 were very similar to the ones observed during the period 1986-1990 (Sader et al. 2000).

As in the MABR, several other factors could account for deforestation patterns in Petén (e.g., governmental development policies, and farmers' economic incentives). However, Sader et al.'s (2000) estimations might suggest that conservation initiatives that not only consider biophysical integrity, but also other contextual circumstances (i. e., the economic needs of local people) are effective for reducing deforestation. Thus, in the MBR, community forest concessions are more effective, in terms of keeping a larger area of standing forest, than national parks. This is not to conclude that community-based management is a panacea for achieving sustainability under any circumstances. For instance, our observations in some specific Petén forest concessions agree with Klooster's (1999) findings that community-based forest management in Mexico led to forest degradation when it was carried out undemocratically. However, as previously stated, the goal of our research is not to defend any particular form of forest management, but to advocate sustainability initiatives designed and implemented in agreement with the consideration of a broad spectrum of contextual circumstances, including as many dimensions as deemed necessary. We are further proposing that deciding which dimensions are the most relevant in each case should be informed by a close examination of human-nature interactions, including the meanings attributed to these interactions by local people. Other authors have reached parts of this conclusion. For example, in the Wolong Nature Reserve for Giant Pandas in China, Liu et al. (2001) observed an increase in forest degradation after the creation of the reserve. These authors recommend the integration of ecology with population change, human behavior, and socioeconomics in order to understand better the effectiveness of protected areas, and to develop enhanced policies.

From our examination of the MF nature-human interactions, we speculate that a deeper consideration of contextual socioeconomic and cultural circumstances could greatly contribute to more effective design and implementation of the next generation of sustainability initiatives.

Regarding the socioeconomic context, a first aspect to be considered is the subsistence and economic needs of the local population. This was considered to a certain extent in the case of the MBR through community-based forestry, which seems to have contributed to the MF biophysical sustainability. However, possibilities of implementing sustainable development projects are often severely limited by either biosphere reserve regulations or unfavorable marketing conditions. Emerging disciplines such as ecological economics and integrated environmental management could provide attractive alternatives to compensate farmers for bearing the full costs of restricting the productive uses of the forest. For 
instance, fair trade mechanisms for farmers' products, or the possibility of implementing carbon mitigation projects as put forward by Klooster and Masera (2000), and Nelson and de Jong (2003).

A second crucial aspect, related more to political ecology approaches, is to develop a better understanding of the conflict dynamics among the diverse stakeholders in the MF. Successful political negotiation is a crucial aspect for the MF sustainability. In the case of Mexico, farmers' almost complete lack of trust in the government and international actors poses a serious impediment to any future attempt to negotiate. The transparent and detailed study of the interest "behind" conservation of international actors (e.g., transnational corporations associated with bioprospecting or oil exploration) and their relationship with governmental bodies might help to reestablish relationships of trust. In the case of Guatemala, the levels of trust and suspicion in relation to international actors are not as pronounced, but there is little trust among farmers, the government, and economic actors, and this is also fuelled by lack of transparency. For instance, since 1998, fires have regularly burned in the MBR core areas during the dry season. There is consensus that most of these fires are of anthropogenic origin. Some intellectuals, conservation personnel, and peasants believe that these fires are started by ranchers, peasants, or oil companies in order to take over the reserve. However, very little reliable information exists regarding the real origin of this significant impact.

A third relevant socioeconomic aspect is related to the improvement of actual economic activities, such as farming and cattle ranching, in order to make them more sustainable and compatible with the forest ecosystems (e.g., organic shade-grown coffee as it is already practiced in some areas of Chiapas, and intensification of cattle ranching). Insights from agro-ecology, sustainable rural development studies, and the sustainable livelihoods paradigm are emerging areas of study that can provide significant insights for future sustainability initiatives. For instance, Ortiz-Espejel and Toledo (1998) examined the minimum land requirements per family in the Mexican humid tropics when applying diversified strategies combining agriculture and forest management. This type of calculation can help to design measures for accommodating land requirements of growing farmer populations under conservation goals.
Regarding the cultural context, human ecology, ethno-ecology, anthropology, and cultural studies are some of the disciplines that can provide useful insights into the meanings assigned by different people to their interactions with their environment. Confrontation in the MABR and MBR is often aggravated by lack of understanding of the others' worldviews and discourses. Characterization of the diverse existing worldviews can contribute to favoring understanding and dialogue by providing logical consistency and legitimacy to the perspectives of the different groups. Haenn (1999) carried out an interesting study on this issue in the adjacent biosphere reserve of Calakmul (Mexico). She explored how different knowledge systems and power issues intersected in the years following the declaration of the reserve. Her results emphasize the key role of actors capable of bringing together distinct ways of thinking about the environment for the success of conservation initiatives. In the case of Chiapas and Petén, conflicting meanings regarding human-nature relationships emerge among farmers, scientists, professionals, and urban/ government elites. Also, there are significant divergences among farmers, depending on their ethnic group, life experiences, and ideological positions. This vast cultural diversity makes it desirable to consider the contextual circumstances of each specific community when applying conservation initiatives. Additionally, in the case of the MF, we recommend sustainability initiatives that include the full complexity of the process of deforestation, encourage dialogue and equity between urban and rural perspectives, and address cultural heterogeneity. Conservation initiatives should be assessed in light of local cosmologies (i. e., beliefs about the fundamental nature of the universe). New institutional arrangements are needed that respect and reflect the mosaic of cultures, peoples, and traditions, rather than assuming that western organizational schemes that emerged and prospered in other parts of the world need to be uncritically reproduced in the MF.

In light of this preliminary assessment, we recommend that design of future MF sustainability initiatives should be informed by the kind of contextual considerations outlined here (which should be improved through interdisciplinary teamwork). The resulting design should consider zoning strategies based not only on ecological criteria, but also on the socioeconomic, political, and cultural heterogeneity of the region. Management practices should also be diversified 
according to the requirements of all organisms (including humans) and systems (including societies). The implementation plans should consider the trade-offs and costs of favoring some interests over others. Economic compensation and political interventions should be identified in order to compensate the groups affected by exclusionary rules by, for example, creating favorable market conditions. We are aware that implementing these types of initiatives would require the establishment of a stronger international political regime toward sustainability than the one presently in place. However, the main purpose of the paper is to show how place-based and integrative-knowledge approaches are efforts to deal with the local context and the complexity of each situation. In this sense, they strive to be inclusive of all peoples and their perspectives, and assume cultural diversity. This has the virtue of trying to deal up front with people, their issues, and contradictions. However, this is initially very costly in time and energy, and is difficult to dissociate from social and cultural change. The trade-offs among up-front investment, inclusivity (which implies messiness), context specificity, and robustness vs. simplicity, generality, tidiness, efficiency, immediacy, fragility, and ineffectiveness, constitute a dilemma that is inescapable when deciding how to undertake sustainability initiatives.

In this paper, we make a strong argument for designing conservation strategies based on considering a range of contextual circumstances within a framework involving multiple disciplines and knowledges. Further study of conservation programs in the field is needed before significant generalizations can be made. The success of any sustainability initiative will ultimately depend on its structural coupling with the context in which it is applied. We aim to contribute to the task of effectively and transparently approaching environmental issues from multiple perspectives. An exercise of contextualization and contrasting is needed not only within the boundaries of particular disciplines, but also across disciplinary boundaries and beyond the boundaries of science.

Responses to this article can be read online at: http://www.ecologyandsociety.org/voll1/iss 1/art8/responses/

\section{Acknowledgments:}

The authors are very grateful to the late Dr. James J. Kay. Many of the basic ideas on which this article is based were conceived and developed with him. Sincere thanks to all the people in Mexico and Guatemala who generously offered help, support, and valuable insights. In particular, to Antonio Choc, Pedro Cuc, Berta Collí, Ileana Valenzuela, and Jorge Cabrera. Many thanks to the Central American Water Resource Management Network (CARA) project, at the University of Calgary and the University of Waterloo-funded by the Canadian International Development Agency-for their financial support. The views expressed in this paper are solely those of the authors.

\section{LITERATURE CITED}

Berkes, F. 2004. Rethinking community-based conservation. Conservation Biology 18(3):621630.

Bobrow-Strain, A. 2004. (Dis)accords: the politics of market-assisted land reforms in Chiapas, Mexico. World Development 32(6):887-903.

Bowles, I. A., R. E. Rice, R. A. Mittermeier, and G. A. B. da Fonseca. 1998. Logging and tropical forest conservation. Science 280(5371):18991900.

Carabias-Lillo, J., E. Provencio, J. De la Maza Elvira, D. Gutiérrez-Carbonell, M. GómezCruz, and A. López-Portillo. 2000. Programa de manejo Reserva de la Biosfera Montes Azules. Instituto Nacional de Ecología- SEMARNAP, Mexico, D.F., Mexico.

Chemonics International Inc. and IRG. 2000. Guatemala: assessment and analysis of progress towards SO5 goals in the Maya Biosphere Reserve. Final report submitted to USAID/G-CAP.

Clark, C. 2000. Land tenure delegitimation and social mobility in tropical Petén, Guatemala. Human Organization 59(4):419-427.

De Vos, J. 2002. Una tierra para sembrar sueños. 
Historia reciente de la selva Lacandona, 19502000. Fondo de Cultura Económica, Mexico, D.F, Mexico.

Emerson, R. M., R. I. Fretz, and L. L. Shaw. 1995. Writing ethnographic fieldnotes. University of Chicago Press, Chicago, Illinois, USA.

Gómez-Pompa, A., and A. Kaus. 1999. From preHispanic to future conservation alternatives: lessons from Mexico. Proceedings of the National Academy of Sciences 96:5982-5986.

Gretzinger, S. P. 1998. Community forest concessions: an economic alternative for the Maya Biosphere Reserve in the Petén, Guatemala. Pages 111-124 in R. B. Primack, D. Bray, H. A. Galletti, and I. Ponciano, editors. Timber, tourists, and temples: conservation and development in the Maya Forest of Belize, Guatemala, and Mexico. Island Press, Washington, D.C., USA.

Haenn, N. 1999. The power of environmental knowledge: ethnoecology and environmental conflicts in Mexican conservation. Human Ecology 27(3):477-491.

Hernández-Gómez, J. M., J. Leopoldo-Castro, B. Benedetta, M. Chamberlin, E. LedesmaArronte. 2003. Conservación internacional: el caballo de Troya. Centro de Análisis Político e Investigaciones Sociales y Económicas. San Cristóbal de las Casas, Chiapas, Mexico.

Kates, R. W., W. C. Clark, R. Corell, J. M. Hall, C. C. Jaeger, I. Lowe, J. J. McCarthy, H. J. Schellnhuber, B. Bolin, N. M. Dickson, S. Faucheux, G. C. Gallopín, A. Gruebler, B. Huntley, J. Jäger, N. S. Jodha, R. E. Kasperson, P. Matson, H. Mooney, B. Moore, III, T. O'Riordan, and U. Svedin. 2001. Sustainability science. Science 292(5517):641-642.

Kline, K. 2000. Desarrollo sostenible y el proyecto de la RBM: desafíos, avances y reflexiones sobre lecciones aprendidas (prespectiva de un donante). Pages 241-253 in Encuentro internacional de investigadores: nuevas perspectivas de desarrollo sostenible en Petén. FLACSO, Guatemala City, Guatemala.

Klooster, D. 1999. Community-based forestry in Mexico: can it reverse processes of degradation? Land Degradation and Development 10:365-381.
Klooster, D., and O. Masera. 2000. Community forest management in Mexico: carbon mitigation and biodiversity conservation through rural development. Global Environmental Change 10:259-272.

Kremen, C., J. O. Niles, M. G. Dalton, G. C. Daily, P. R. Ehrlich, J. P. Fay, D. Grewal, and R. P. Guillery. 2000. Economic incentives for rain forest conservation across scales. Science 288(5472):18281832.

Leyva-Solano, X., and G.Ascencio-Franco. 1996. La lacandona al filo del agua. Fondo de Cultura Económica, Mexico, D.F. Mexico.

Liu, J., M. Linderman, Z. Ouyang, L.An, J. Yang, and H. Zhang. 2001. Ecological degradation in protected areas: the case of Wolong Nature Reserve for giant pandas. Science 292(5514): 98-101.

Manuel-Navarrete, D. 2005. Challenges and opportunities of metadisciplinary place-based research: the case of the Maya forest. Environments: a Journal of Interdisciplinary Studies 33(1):81-98.

Manuel-Navarrete, D., J. J. Kay, and D. Dolderman. 2004. Ecological integrity discourses: linking ecology with cultural transformation. Human Ecology Review 11(3):215-229.

Maruyama, M. 1994. Most frequently found mindscapes. Pages 1-28 in M. T. Caley and D. Sawada, editors. Mindscapes. The epistemology of Magoroh Maruyama. Gordon and Breach Science Publishers, Langhorne, Pennsylvania, USA.

Mendoza, E., and R. Dirzo. 1999. Deforestation in Lacandonia (southeast Mexico): evidence for the declaration of the northernmost tropical hotspot. Biodiversity and Conservation 8:1621-1641.

Michel, G. 2001. Votán Zapata. Filósofo de la esperanza. Rizoma, Mexico D.F., Mexico.

Milián, B., G. Grünberg, and M. Cho-Botzoc. 2002. La conflictividad agraria en las Tierras bajas del norte de Guatemala: Petén y la franja transversal del Norte. FLACSO-MINUGUACONTIERRA, Guatemala City, Guatemala.

Nelson, K. C., and B. H. J. de Jong. 2003. Making global initiatives local realities: carbon mitigation projects in Chiapas, Mexico. Global Environmental 
Change 13:19-30.

Ortiz-Espejel, B., and V. M. Toledo. 1998. Tendencias en la deforestación de la Selva Lacandona (Chiapas, Mexico): el caso de las Cañadas. Interciencia 23(6):318-328.

Ponciano, I. 1998. Forestry policy and protected areas in the Petén, Guatemala. Pages 99-110 in R. B. Primack, D. Bray, H. A. Galletti, and I. Ponciano, editors. Timber, tourists, and temples: conservation and development in the Maya forest of Belize, Guatemala, and Mexico, Island Press, Washington, D.C., USA.

Rice, R. E., C. A. Sugal, S. M. Ratay, and G. A. B. Fonseca. 2001. Manejo forestal sostenible: revisión del saber convencional. Center for Applied Biodiversity Science, Conservation International, Washington D.C., USA. Advances in Applied Biodiversity Science 3:1-35.

Sader, S. A., E. Bernales-Martínez, D. E. Irwin, and H. Tuy-Yax. 2000. Estimación de la deforestación en la Reserva de la Biosfera Maya 1997-1999. Pages 321-324 in Encuentro internacional de investigadores: nuevas perspectivas de desarrollo sostenible en Petén. FLACSO, Guatemala City, Guatemala.

Strand, R. 2001. Radical visions of environmental science. Norwegian Journal of Sociology 9:49-67.

Subcomandante Marcos. 2004. Relatos de El Viejo Antonio. Virus, Barcelona, Spain.

Sundberg, J. 1998. NGO landscapes: conservation and communities in the Maya Biosphere Reserve, Petén, Guatemala. Geographical Review $\mathbf{8 8}$ (3):388-412.

Toledo, V. M. 2000. La paz en Chiapas: ecología, luchas indígenas y modernidad alternativa. Ediciones Quinto Sol, Mexico, D.F., Mexico.

U.S. Agency for International Development. 1990. Maya Biosphere Reserve project. USAID/ Guatemala Mission, Guatemala City, Guatemala.

Vásquez-Sánchez, M. A., I. J. March, and M. A. Lazcano-Barrero. 1992. Características socioeconómicas de la Selva Lacandona. Pages 287-324 in M. A. Vásquez-Sánchez and M. A. Ramos-Olmos, editors. Reserva de la Biosfera Montes Azules, Selva
Lacandona: investigación para su conservación. Publicaciones Especiales Exosfera, Mexico, D.F., Mexico. 